\title{
Factors associated with decision making power of women to use family planning among married women in sub-Saharan Africa: A multilevel analysis of demographic health surveys
}

Getu Debalkie Demissie ( $\nabla$ getud2006@gmail.com )

University Of Gondar

Yonas Akalu

University Of Gondar

Abebaw Addis Gelagay

University Of Gondar

Wallelign Alemnew

University Of Gondar

Yigizie Yeshaw

University Of Gondar

\section{Research Article}

Keywords: women decision making power, family planning, sub-Saharan Africa

Posted Date: February 16th, 2021

DOI: https://doi.org/10.21203/rs.3.rs-156535/v1

License: (c) (i) This work is licensed under a Creative Commons Attribution 4.0 International License.

Read Full License 


\section{Abstract}

Background: In sub-Saharan Africa there are several socio-economic and cultural factors which affect women's ability to make decision regarding their own health including contraceptive usage. The main aim of this study was to determine factors associated with decision making power of women to use family planning in sub-Saharan Africa.

Methods: The appended, most recent demographic and health survey datasets of 35 sub-Saharan countries were used. A total weighted sample of 83,882 women were included in the study. Both bivariable and multivariable multilevel logistic regression were done to determine the associated factors of decision making power of women to use family planning in SSA. The Odds Ratio (OR) with a 95\% Confidence Interval $(\mathrm{Cl})$ was calculated for those potential variables included in the final model.

Results: Those married women with primary education ( $\mathrm{AOR}=1.24 ; \mathrm{Cl}: 1.16,1.32)$,secondary education $(A O R=1.31 ; \mathrm{Cl}: 1.22,1.41)$, higher education ( $A O R=1.36$; $\mathrm{Cl}: 1.20,1.53)$, media exposure(AOR=1.08; $\mathrm{Cl}$ : 1.03, 1.13), currently working (AOR=1.27; $\mathrm{Cl}$ : 1.20, 1.33), antenatal care visit of 1-3 (AOR=1.12; $\mathrm{Cl}: 1.05,1.20)$ and $\geq 4$ ANC visit (AOR=1.14;Cl:1.07,1.21), women who were informed about family planning ( $A O R=1.09 ; \mathrm{Cl}$ :

$1.04,1.15)$, women who had less than 3 children(AOR=1.12; $\mathrm{Cl}: 1.02,1.23)$ and $3-5$ children (AOR=1.08; $\mathrm{Cl}$ : $1.01,1.16)$ had higher odds of decision making power to use family planning than their counter parts.

Besides, mothers with age of 15-19 (AOR=0.61; Cl: 0.52, 0.72), 20-24 (AOR= 0.69; Cl: 0.60, 0.79), 25-29 $(A O R=0.74 ; \mathrm{Cl}: 0.66,0.84)$, and $30-34$ years $(A O R=0.82 ; \mathrm{Cl}: 0.73,0.92)$ had reduced chance of decision making power of women to use family planning.

Conclusion: Age, women's level of education, occupation of women and their husband, wealth index, media exposure, ANC visit, fertility preference, husband's desire number of children, region and information about family planning were factors associated with decision making power to use family planning among married women.

\section{Background}

Sub-Saharan Africa accounted $66 \%$ of the deaths globally and had the highest Maternal Mortality Ratio (MMR) at 546 maternal deaths per 100,000 live births(1). Unplanned pregnancy and short inter-pregnancy spacing are leading causes of maternal and child death in this region; use of modern family planning methods after delivery is considered an important part of interventional efforts $(2,3)$. In developing countries, more than 222 million women's pregnancies are unplanned(4).

The 2030 Agenda for Sustainable Development Goal(SDGs) includes relevant targets for using contraceptive under the broader goals of health and well-being of the population and gender equality (5, 6). Family planning service contributes not only to the reduction of morbidity and mortality of mothers and children, but also avoiding unintended pregnancy and its adverse consequence including preventing HIV/AIDS and high risk abortion, improving standard of living, and efficient use of natural resources(7). 
Only $17 \%$ of married women are using contraceptives in sub-Saharan Africa which is too low as compared to North Africa( 50\%), Middle East (39\%), East Asia (76\%) and Latin America $(68 \%)(8,9)$. Although $30 \%$ of maternal deaths and $10 \%$ of child death could be avoided by extending pregnancy (10), $41 \%$ of women in Sub-Saharan Africa who intended to use modern contraceptives were not using (11).

A woman's ability to choose the method of modern contraception she uses are likely to be affected by her self-image and sense of empowerment. A woman who feels that she is unable to control other aspects of her life may be less likely to feel that she can make decisions about fertility(12). Independent decision making or joint decision making with partners on family planning use has a substantial contribution to the improvement of maternal health(13). Although women's empowerment is a key to use contraceptives(12), most of husbands give inferior positions to women in all aspects of decision-making in developing countries including decision making power to use contraceptives $(12,14)$.

Women often have less power due to their political, economic, and sociocultural status and may not be in a position to protect themselves from unwanted sexual intercourse and gender-based violence and resulting in sexually transmitted infections and other sexual and reproductive health (SRH) problems(15). This indicates that gender inequalities worsen a difference in SRH well-being and ill health, and sometimes life and death(16).

One of the reasons women have reported for their nonuse of contraceptive is that they do not decide to use or not to use it(17). Evidences showed that women who have decision-making power are more likely to use contraceptive than those who had not $(18,19)$. However, decisions for contraceptive use may be affected by unbalanced power relations between women and their partners, especially in more malecontrolled societies and cultural discrimination (20). Furthermore, previous studies showed that decisionmaking power of women to use family planning was associated with education $(4,21-23)$, age $(4,23-$ $26)$, better knowledge $(24,27,28)$, working status of women $(25,26,29)$, gender equitable attitude(27), number of living children $(21,25,26)$, socio-economic status $(22,23,29-31)$, residence $(25,26)$, husband desire number of children(28) and attitude towards family planning(24).

Despite decision making power of women to use family planning is a huge problem in SSA region, to the best of our knowledge, there is no study that investigates the factors associated with decision making

power to use family planning among married women in the region. Hence, this study was conducted to fill the gap in literature in determining the associated factors of decision making power of women to use family planning in sub-Saharan Africa, which in turn highly relevant to recommend the design and implementation strategies of decision making power of women to use family planning in the region.

\section{Methods}

\section{Data source}

This study used the most recent appended demographic and health survey (DHS) datasets of 35 subSaharan countries which were conducted from 2009 to 2018. The DHS is a nationally representative 
survey, collected every five years, to provide population and health indicators at the national and regional levels. A pretested standard Demographic and Health Survey questionnaires were used for data collection of the DHS surveys. The questionnaire was conceptualized to the different countries context and the data were collected by trained data collectors. The datasets of each sub Saharan country were obtained at https://dhsprogram.com/data/dataset_admin/index.cfm. Those countries with no data on decision making power of women to use family planning were excluded from the analysis. In this study, a total weighted sample of 83,882 women were included (Table 1 ). 
Table 1

List of sub-Saharan countries included, and their demographic and health Survey's year

\begin{tabular}{|ll|}
\hline Country name & Survey year \\
\hline Angola & $2015 / 16$ \\
\hline Burkina Faso & 2010 \\
\hline Benin & $2017 / 18$ \\
\hline Burundi & $2016 / 17$ \\
\hline Cameroon & 2018 \\
\hline Congo Democratic Congo & $2013 / 14$ \\
\hline Chad & 2015 \\
\hline Comoros & 2012 \\
\hline Congo & $2011 / 12$ \\
\hline Cote d'vore & $2011 / 12$ \\
\hline Ethiopia & 2016 \\
\hline Gabon & 2012 \\
\hline Ghana & 2014 \\
\hline Gambia & 2013 \\
\hline Guinea & 2018 \\
\hline Kenya & 2014 \\
\hline Liberia & 2013 \\
\hline Lesotho & 2014 \\
\hline Madagascar & 2009 \\
\hline Mali & 2018 \\
\hline Malawi & $2015 / 16$ \\
\hline Mozambique & 2011 \\
\hline Nigeria & 2018 \\
\hline Niger & $2012 / 15$ \\
\hline Namibia & 2013 \\
\hline Rwanda & 2018 \\
\hline
\end{tabular}




\begin{tabular}{|ll|}
\hline Country name & Survey year \\
\hline Sera lone & 2016 \\
\hline Sao tome and Principe & 2009 \\
\hline Senegal & 2011 \\
\hline Togo & 2013 \\
\hline Tanzania & $2015 / 16$ \\
\hline Uganda & 2016 \\
\hline South Africa & 2016 \\
\hline Zambia & 2018 \\
\hline Zimbabwe & 2015 \\
\hline
\end{tabular}

\section{Variables of the study}

\section{Dependent variable}

The dependent variable for this study was decision making power of women to use family planning. According to DHS, decision making power of women to use family planning was reported in four categories (decision making by women, partner, joint and others). Hence, we dichotomized this variable as: yes (if the women decide independently or together with their partner/husbands to use family planning) and no (if the decision making to use family planning was made by their partner/husbands only or others)(24).

\section{Independent variables}

Both individual and community level variables were considered as independent variables. The individual level variables were age, education level, wealth index, occupational status of women and their husbands, media exposure, ANC visit, number of living children, desire fertility of women, desire number of children by husbands, and information related to FP at health facility. Residence and SSA region were the community level factors included in this study.

\section{Data analysis procedure}

We used STATA 14 software to extract, recode and analyze the data. The data were weighted before doing any statistical analysis to restore the representativeness of the sample and get a reliable estimate and standard error. The whole procedure of weighting and its rationale is found on the guide of DHS statistics (32).

Due to the correlated nature of DHS data, measures of community variation/random-effects such as Median Odds Ratio (MOR), Interclass Correlation Coefficient (ICC), and Proportional Change in Variance 
(PCV) were calculated. Accordingly, the values of these measures were found to be significant, and hence the use of multilevel logistic regression model is more appropriate than using ordinary logistic regression. To choose the best fitted model, first we developed four models and compared them with Deviance. These were: the null-model; a model with no independent variable, model I ; a model that have individuallevel factors only, model II; a model with community-level factors only and model III; a model that contain both community level and independent variables. Of the four models fitted, model III was selected as best fitted model (it had the lowest Deviance).

Then after, both bivariable and multivariable multilevel logistic regression was performed to determine the associated factors of decision making power of women to use FP in SSA. All variables which has a $p$ value $<0.25$ during bi-variable analysis were entered into the multivariable logistic regression model. In the final model, we used $p$ value $\leq 0.05$ to declare statistically significant variables.

\section{Results}

\section{Sociodemographic characteristics of the respondents}

The total weighted samples of 83,882 married women were included in this study. Of these, $22.9 \%$ of the respondents were in the age group of 25-29 years and while more than half $(60 \%)$ of the respondents were live in rural area. More than one-third of both the respondents (39.9\%) and their husbands (34.4\%) had primary education level. Majority of the respondents (73.3\%) and their husbands (92.7\%) were currently working /employed. Similarly majority of the study participants $(67 \%)$ had media exposure (Table 2). 
Table 2

Sociodemographic characteristics of the respondents in sub-Saharan Africa

\begin{tabular}{|c|c|c|c|}
\hline \multicolumn{2}{|l|}{ Variable Category } & \multirow{2}{*}{$\begin{array}{l}\text { Weighted Frequency } \\
3,215\end{array}$} & \multirow{2}{*}{$\begin{array}{l}\text { Percent (\%) } \\
3.8\end{array}$} \\
\hline Age(in years) & $15-19$ & & \\
\hline & $20-24$ & 13,693 & 16.0 \\
\hline & $25-29$ & 19,210 & 22.9 \\
\hline & $30-34$ & 17,890 & 21.0 \\
\hline & $35-39$ & 15,016 & 17.9 \\
\hline & $40-44$ & 9,794 & 11.9 \\
\hline & $45-49$ & 5,063 & 6.5 \\
\hline \multirow[t]{2}{*}{ Residence } & Urban & 33,704 & 40.0 \\
\hline & Rural & 50,177 & 60.0 \\
\hline \multirow[t]{4}{*}{ Region } & East Africa & 37,713 & 44.7 \\
\hline & West Africa & 19,471 & 24.0 \\
\hline & South Africa & 15,430 & 18.6 \\
\hline & Central Africa & 10,534 & 12.7 \\
\hline \multirow[t]{4}{*}{ Education level of respondents } & No formal education & 16,714 & 19.9 \\
\hline & Primary & 33,490 & 39.9 \\
\hline & Secondary & 28,100 & 33.5 \\
\hline & Higher & 5,578 & 6.7 \\
\hline \multirow[t]{4}{*}{ Education level of husband } & No formal education & 15,251 & 18.2 \\
\hline & Primary & 28,865 & 34.4 \\
\hline & Secondary & 30,280 & 36.0 \\
\hline & Higher & 9,406 & 11.0 \\
\hline \multirow[t]{3}{*}{ Respondents' occupations } & Currently working & 61,454 & 73.3 \\
\hline & Currently & 22,428 & 26.7 \\
\hline & Not working & & \\
\hline \multirow[t]{3}{*}{ Husbands occupations } & Currently working & 77,741 & 92.7 \\
\hline & Currently & 6,141 & 7.3 \\
\hline & Not working & & \\
\hline
\end{tabular}




\begin{tabular}{|llll|}
\hline Variable Category & & Weighted Frequency & Percent (\%) \\
\hline Wealth index & Poorest & 10,934 & 13 \\
\hline Poorer & 14,093 & 16.8 \\
\hline Middle & 16,119 & 19.4 \\
\hline Richer & 19,309 & 23 \\
\hline Richest & 23,425 & 27.8 \\
Media exposure & Yes & 56,269 & 67.0 \\
& No & 27,585 & 33.0 \\
\hline
\end{tabular}

\section{Reproductive characteristics of the respondents}

Of the respondents, $47.6 \%$ of them had four and more ANC visit. Majority of the respondents $(69.2 \%)$ were told about family planning methods during their facility visit. More than half of the respondents $(56 \%)$ had fertility preference to have other children. Regarding contraceptive methods used, $36.2 \%$ of study participants used injections (Table 3). 
Table 3

; Reproductive characteristics of the respondents in sub-Saharan Africa

\begin{tabular}{|c|c|c|c|}
\hline Variables Category & & Frequency & $\begin{array}{l}\text { Percent } \\
(\%)\end{array}$ \\
\hline \multirow[t]{3}{*}{ Number of ANC visit } & 0 & 24,679 & 29.4 \\
\hline & $1-3$ & 19,255 & 23 \\
\hline & $\geq 4$ & 39,948 & 47.6 \\
\hline \multirow[t]{3}{*}{ Number of living children } & $<3$ & 32,908 & 39.2 \\
\hline & $3-5$ & 38,515 & 45.9 \\
\hline & $>5$ & 12,458 & 14.9 \\
\hline \multirow[t]{3}{*}{ Fertility preference } & Unable to have children & 5100 & 6 \\
\hline & Do not want another children & 31,887 & 38 \\
\hline & Want to have another children & 46,895 & 56 \\
\hline \multirow{2}{*}{$\begin{array}{l}\text { information about FP at health } \\
\text { facility }\end{array}$} & Yes & 25,844 & 30.8 \\
\hline & No & 58,037 & 69.2 \\
\hline \multirow[t]{3}{*}{ Husbands desire for children } & The same with spouse & 37,187 & 44 \\
\hline & Husbands wants more & 39,023 & 46.5 \\
\hline & Husbands wants fewer & 7,671 & 9.5 \\
\hline \multirow{10}{*}{$\begin{array}{l}\text { Type of contraceptive method } \\
\text { used }\end{array}$} & Pill & 12,892 & 15.4 \\
\hline & IUD & 2,292 & 2.73 \\
\hline & Injections & 30,380 & 36.2 \\
\hline & Male condom & 7,236 & 8.6 \\
\hline & Female sterilization & 4,305 & 5 \\
\hline & Periodic abstinence & 6,703 & 8 \\
\hline & Withdrawal & 3,777 & 4.5 \\
\hline & Implants /Norplant & 12,311 & 14.7 \\
\hline & Lactation amenorrhea (LAM) & 1,776 & 2.2 \\
\hline & $\begin{array}{l}\text { Other methods (including traditional } \\
\text { method) }\end{array}$ & 2205 & 2.7 \\
\hline
\end{tabular}


The random-effects model result showed that there is significant clustering of decision making power of women to use family planning across the communities (OR of community level variance $=0.07,95 \% \mathrm{Cl}=$ $0.06-0.10)$. The value of ICC in the null model revealed that $2.16 \%$ of the overall variation of decision making power of women to use family planning was attributed to cluster variability. The 1.23 MOR value of the null model also indicates the presence of variation in the decision making power of women to use family planning between clusters. It means if we randomly select households from different clusters, those households at the cluster with higher decision making power of women to use family planning had 1.23 times higher chance of decision making power to use family planning compared to their counterparts. As you can see in the Table 3 below, model III has the lowest Deviance value. Hence, it was selected as best fitted model (Table 4).

Table 4

Model comparison and random effect analysis result

\begin{tabular}{|lllll|}
\hline Parameters & Null model & Model I & Model II & Model III \\
\hline Community level & $0.07(0.06-$ & $0.07(0.06-$ & $0.07(0.05-$ & $0.07(0.05-$ \\
variance & $0.10)$ & $0.10)$ & $0.09)$ & $0.09)$ \\
\hline ICC & $2.16 \%$ & $2.14 \%$ & $2.00 \%$ & $2.02 \%$ \\
\hline MOR & 1.29 & 1.29 & 1.28 & 1.28 \\
\hline PCV & Ref & $0.69 \%$ & $7.42 \%$ & $6.60 \%$ \\
\hline Model fitness & & & & \\
\hline Deviance & 54592.124 & 53855.498 & 53915.178 & 53310.886 \\
\hline
\end{tabular}

\section{Factors associated with decision making to use contraceptive}

The odds of decision making power to use family planning among married women with age 15-19, 20$24,25-29$ and $30-34$ years was decreased by $39 \%(\mathrm{AOR}=0.61 ; \mathrm{Cl}: 0.52,0.72), 31 \%(\mathrm{AOR}=0.69 ; \mathrm{Cl}: 0.60$, $0.79), 26 \%(\mathrm{AOR}=0.74 ; \mathrm{Cl}: 0.66,0.84)$, and $18 \%(\mathrm{AOR}=0.82 ; \mathrm{Cl}: 0.73,0.92)$ as compared to their counterparts, respectively. The odds of decision making power to use family planning among married women whose education level was primary, secondary and higher was about 1.24 ( $A O R=1.24$; $\mathrm{Cl}: 1.16,1.32), 1.31(\mathrm{AOR}=1.31 ; \mathrm{Cl}: 1.22,1.41)$ and $1.36(\mathrm{AOR}=1.36 ; \mathrm{Cl}: 1.20,1.53)$ times higher compared to those who did not have formal education.

Women who are currently working were $1.27(\mathrm{AOR}=1.27 ; \mathrm{Cl}: 1.20,1.33)$ times more likely to have decision making power to use contraceptive as compared to women who were not currently working. Women who had media exposure were $1.1(\mathrm{AOR}=1.08 ; \mathrm{Cl}: 1.03,1.13)$ times more likely to have decision making power on family planning use as compared to those women who did not had media exposure. 
Similarly, the odds of decision making power on family planning among participants who had 1-3 and $\geq 4$ ANC visit was increased by $12 \%(\mathrm{AOR}=1.12 ; \mathrm{Cl}: 1.05,1.20)$ and $14 \%(\mathrm{AOR}=1.14 ; \mathrm{Cl}: 1.07,1.21)$ than those who had not ANC visit, respectively. Besides, the odds of decision making power on family planning among participants who had informed about family planning was increased by $9 \%(A O R=1.09 ; \mathrm{Cl}: 1.04$, $1.15)$ than their counterparts. Women whose husband's desire want fewer children $14 \%(\mathrm{AOR}=0.86 ; \mathrm{Cl}$ : $0.79,0.93)$ reduced chance of decision making power for family planning than their counterparts.

Women who had less than 3 and $3-5$ children were 1.12 (AOR = 1.12; $\mathrm{Cl}: 1.02,1.23)$ and 1.08 (AOR = 1.08; $\mathrm{Cl}: 1.01,1.16)$ times higher odds of decision making power to use family planning than women who had $>5$ children, respectively. Women who did not have children were $48 \%$ reduced odds of decision making power to use FP than women who want to have children ( $A O R=0.52 ; \mathrm{Cl}: 0.47-0.58)$. Moreover, the odds of decision making power to use FP was increased by $1.12(\mathrm{AOR}=1.10 ; \mathrm{Cl}: 1.04,1.17)$ times among participants who do not want other children than those who wants to have other children (Table 5). 
Table 5

; multilevel regression analysis of decision making power to use family planning among married women in sub-Saharan Africa

\section{Decision making Odds ratio}

Variables

Age (years)

$15-19$

$20-24$

$25-29$

$30-34$

$35-39$

$40-44$

$45-49$

Residence

Urban

Rural

Region

East Africa

West Africa

South Africa

Central Africa

Education level of respondents

No education

Primary
Yes, No (\%) No, No (\%) $\quad$ COR $(95 \% \mathrm{Cl}) \quad$ AOR(95\%Cl)

$\begin{array}{llll}2797(87) & 418(13) & 0.76(0.66- & 0.61(0.52- \\ & & 0.87) & 0.72)^{\star}\end{array}$

12,167(88.9) 1526(11.1)

$0.91(0.81-$

1.00)

$0.69(0.60-$

$0.79)$ *

$\begin{array}{llll}17,144(89.3) & 2066(10.7) & 0.96(0.87- & 0.74(0.66- \\ & & 1.07) & 0.84)^{\star}\end{array}$

$16,092(89.9)$

1799(10.1)

1.04(0.94-

1.05)

$0.82(0.73-$

$0.92)^{*}$

$\begin{array}{llll}13,506(89.9) & 1510(10.1) & 1.06(0.95- & 0.89(0.79- \\ & & 1.17) & 1.00)\end{array}$

$8,798(89.8) \quad 996(10.2)$

1.01(0.91-

1.13)

$0.92(0.82-$ 1.02)

$4527(89.5)$

536(10.6)

1

1

\begin{tabular}{llll}
$30,082(89.3)$ & $3622(10.7)$ & 1 & 1 \\
\hline $5229(10.4)$ & $44,949(89.6)$ & $\begin{array}{l}1.01(0.97- \\
1.06)\end{array}$ & $\begin{array}{l}1.02(0.96- \\
1.08)\end{array}$
\end{tabular}




\begin{tabular}{|c|c|c|c|c|}
\hline \multirow[b]{2}{*}{ Secondary } & \multicolumn{2}{|c|}{ Decision making } & \multicolumn{2}{|l|}{ Odds ratio } \\
\hline & $25,250(89.9)$ & $2,851(10.1)$ & $\begin{array}{l}1.40(1.32- \\
1.49)\end{array}$ & $\begin{array}{l}1.31(1.22- \\
1.41)^{\star}\end{array}$ \\
\hline Higher & $5,093(91.3)$ & 485(8.7) & $\begin{array}{l}1.66(1.49- \\
1.85)\end{array}$ & $\begin{array}{l}1.36(1.20- \\
1.53)^{\star}\end{array}$ \\
\hline \multicolumn{5}{|c|}{ Respondents' occupations } \\
\hline working & $55,489(90.3)$ & $5,965(9.7)$ & $\begin{array}{l}1.35(1.29- \\
1.42)\end{array}$ & $\begin{array}{l}1.27(1.20- \\
1.33)^{\star}\end{array}$ \\
\hline not working & $19,542(87)$ & 2,886(13) & 1 & 1 \\
\hline \multicolumn{5}{|c|}{ Husband's occupation } \\
\hline working & $69,705(89.7)$ & $8,035(10.3)$ & $\begin{array}{l}1.24(1.15- \\
1.35)\end{array}$ & $\begin{array}{l}1.17(1.08- \\
1.27)^{\star}\end{array}$ \\
\hline not working & $5,326(86.7)$ & 816(13.30 & 1 & 1 \\
\hline \multicolumn{5}{|l|}{ Wealth index } \\
\hline Poorest & $9,656(88.3)$ & $1,277(11.7)$ & 1 & 1 \\
\hline Poorer & $1,558(11.1)$ & $12,535(88.9)$ & $\begin{array}{l}1.06(0.98- \\
1.18)\end{array}$ & $\begin{array}{l}1.01(0.93- \\
1.09)\end{array}$ \\
\hline Middle & $1,736(11)$ & 14,383(89) & $\begin{array}{l}1.09(1.01- \\
1.18)\end{array}$ & $\begin{array}{l}1.01(0.94- \\
1.09)\end{array}$ \\
\hline Richer & $2,071(10.3)$ & $17,239(89.3)$ & $\begin{array}{l}1.12(1.04- \\
1.20)\end{array}$ & $\begin{array}{l}1.02(0.94- \\
1.11)\end{array}$ \\
\hline Richest & $2,208(9.4)$ & $21,217(0.6)$ & $\begin{array}{l}1.28(1.19- \\
1.38)\end{array}$ & $\begin{array}{l}1.13(1.03- \\
1.23)^{\star}\end{array}$ \\
\hline \multicolumn{5}{|c|}{ Media exposure } \\
\hline Yes & $50,675(90.1)$ & $5,594(10.9)$ & $\begin{array}{l}1.19(1.14- \\
1.26)\end{array}$ & $\begin{array}{l}1.08(1.03- \\
1.13)^{\star}\end{array}$ \\
\hline No & 24,335(88.2) & $3,251(11.8)$ & 1 & 1 \\
\hline \multicolumn{5}{|l|}{ ANC visit } \\
\hline no ANC visit & $21,972(89)$ & $2,708(11)$ & 1 & 1 \\
\hline 1-3 ANC visit & $1,964(10.2)$ & 17,291(89.8) & $\begin{array}{l}1.08(1.02- \\
1.51)\end{array}$ & $\begin{array}{l}1.12(1.05- \\
1.20)^{\star}\end{array}$ \\
\hline$\geq 4$ ANC visit & $4,179(10.5)$ & $35,769(89.5)$ & $\begin{array}{l}1.06(1.01- \\
1.12)\end{array}$ & $\begin{array}{l}1.14(1.07- \\
1.21)^{\star}\end{array}$ \\
\hline
\end{tabular}


Decision making

Number of living children

$<3$

$29,429(89)$

$3,749(11)$

1.06(0.99-

1.13)

$1.12(1.02-$

$1.23)^{*}$

$3-5$

$34,552(89.7) \quad 3,964(10.3)$

$1.09(1.02-$

1.17)

$1.08(1.01-$

$1.16)^{*}$

$>5$

11,050(88.7) 1,408(11.3)

1

1

Fertility preference

who did not have children

$4,300(84.3) \quad 800(15.7)$

0.68(0.63-

$0.74)$

$0.52(0.47-$

$0.58)$ *

Do not want other children

$29,101(91.3)$

$2,786(8.7)$

$1.29(1.23-$

1.36)

$1.10(1.04-$

1.17)*

Want to have other children

$41,630(88,8)$

$5,265(11.2)$

1

1

Women who are told FP at health

facility

Yes

$23,291(90.1) \quad 2,553(9.9)$

$1.13(1.08-$

1.19)

$1.09(1.04-$

$1.15)^{\star}$

No

$51,739(89.2)$

$6,298(10.8)$

1

1

Husband's desire for children

The same with spouse

$33,656(90.5)$

$3,531(9.5)$

$1.22(1.17-$

1.28)

$0.99(0.94-$ 1.04)

Husbands wants more

$34,518(88.5)$

4,505(11.5)

1

1

Husbands wants fewer

$6,856(89.4)$

815(10.6)

1.07(0.98-

1.16)

$0.86(0.79-$

$0.93)^{\star}$

${ }^{*}$ P-value $\leq 0.05$

\section{Discussion}

The main aim of this study was to determine associated factors of decision making power to use family planning among married women in sub-Saharan Africa. Accordingly this study; age, education level of women, women and their husbands' occupation, wealth index, region, media exposure, ANC visit, fertility preference of the women, husband's desire for the number of children and information about family planning were factors associated with decision making power of women to use family planning. 
As this study showed older women were more likely have decision making power to use FP. This finding is similar to a study conducted in Ethiopia(26), Mozambique(33) and Bangladesh(34). This might be due to if a woman gets more aged, she may feel more self-confident to decide on family planning use individually and by discussing with her husband (35). In most African countries context, young women might not be expected to argue with their older husbands and are required to respect their opinions at all time which might be responsible for low decision making power of women to use FP.

The present study revealed that education level of women was associated with decision making power of women to use FP. Consistently, other studies also showed that women who were more educated were higher odds of decision making power to use family planning $(4,25,35,36)$. Education improves women's control over their reproductive choices by increasing women's position within the family and educated women are more likely to desire smaller families than others and hence have a stronger motivation to practice contraceptives(37).

This study showed that those women and their husbands who were currently working contribute to decision making power of women to use FP. This finding is similar with other studies in Malawi(38), Ethiopia (4), Nigeria(39) and South Asia(40). Women who had occupation might have power and resources and consequently independent in making decisions since they may not depend on their spouses for every resource compared to those who had no occupation. Besides, women whose husbands had occupation may improve the family life generally and this may contribute in women decision making power to use FP indirectly.

Similarly wealth index was positively associated with decision making power of women. Those women from a household with richest wealth index had higher chance of decision making power to use FP than the poorest one. This finding is in line with other previous studies which explain that women's economic status impacts their health and decision-making power on contraceptive usage (41-43). Women who had more income might have access and exposure to mass media about contraceptive and hence increase the likelihood of women decision making power to use contraceptive. Furthermore, in this study, media exposure was also associated with women decision making power to use FP which is in line with other studies $(26,39)$. Mass media helps to increase the decision making power of women to use contraceptive(27).

In the present study we observed that women who had more children were less likely to have decision making power on contraceptive use as compared to those who had fewer children. This finding seems odd and contrast with other studies $(21,25)$. This might be due to related to some religions which teach their followers no to use any modern family planning methods. On the other hand, in this study we also observed that women whose husbands' had high desire number of children had poor decision making power to use FP. This finding was similar to a study conducted in Hondurans(44) and Ethiopia(28). This could be related to husbands might influence women not to use FP especially in developing countries. Hence, awareness on the importance of FP should be given not only for women but also for their husbands. 
In this study women who were informed about FP at health facility had more decision making power to use FP compared to their counterparts. This finding is consistent with other studies $(45,46)$. The implication of this finding is those women who have information and knowledge about family planning could help them to discuss and influence their husbands. Similarly this study showed that those women who had ANC visit had more likely to have decision making power to use family planning for next. This finding was also consistent with other studies $(22,47)$. This might be due to as women go to health facilities for ANC service, they could be getting health information including family planning.

One of the strength of this study is using a very huge and representative datasets of 35 sub-Saharan countries which makes the finding of the study to be generalizable for the region. The other strength of this study is the use of multilevel modeling, a model that accounts the nested/hierarchical nature of the demographic and health survey to get reliable estimates. However, the study has also limitation. Because of the secondary nature of the study, we are unable to assess self-stem and others similar psychological variables which could have strong association with the decision making power of the women to use family planning.

\section{Conclusion}

Age, women level of education, women and their husband's occupation, wealth index, media exposure, ANC visit, fertility preference, husband's desire for the number of children, region and information about family planning were factors associated with decision making power to use family planning among married women. Behavior change interventions including health education and promotion in this region should target on young married women, women who are not educated, women who are not currently working and whose husband's desire more number of children to improve the decision making power of women to use family planning.

\section{List Of Abbreviations}

ANC: Antenatal Care

DHS: Demographic and Health Surveys

FP: Family Planning

MMR: Maternal Mortality Ratio

SRH: Sexual Reproductive Health

SSA: sub-Saharan Africa;

WHO: World Health Organization

\section{Declarations}




\section{Ethics approval and consent to participate}

Since we have used a secondary analysis of DHS data, obtaining ethical approval was not needed. However, we have received a permission letter to download and used the data files from DHS Program. Anyone who wants to use the DHS data can obtain from the DHS Program website (https://dhsprogram.com/data/dataset_admin/index.cfm) after reasonable request.

\section{Consent for publication}

Not applicable

\section{Availability of data and materials}

All data related to the study were included in the manuscript.

\section{Competing interests}

All authors declare that they have no competing interests

\section{Funding}

There was no funding for this study.

\section{Authors' contributions}

GDD and YY designed the study, analyzed the data and drafted the manuscript. YA, WA and AAG were involved in the analysis of the data and critically reviewed the article. All authors read and approved the final manuscript

\section{Acknowledgments}

We would like to express our thanks to the MEAUSRE DHS Program for providing the dataset for this study.

\section{References}

1. WHO. Trends in Maternal Mortality:1990-2015, Estimates by WHO,UNICEF,UNFPA: The World Bank and the United Nations Population Division. Geneva, Switzerland: World Health Organization, , 2015a.

2. Singh S, Sedgh G, Hussain R. Unintended pregnancy: worldwide levels, trends, and outcomes. Stud Fam Plan. 2010;41:241-50.

3. Hubacher D, Mavranezouli I, McGinn E. Unintended pregnancy in subSaharan Africa: magnitude of the problem and potential role of contraceptive implants to alleviate it. . Contraception. 2008;78:73-8. 
4. Belay A, Mengesha Z, Woldegebriel M, Gelaw Y. Married women's decision making power on family planning use and associated factors in Mizan-Aman, South Ethiopia: a cross sectional study. . BMC Womens Health. 2016;16(1):12.

5. United Nations General Assembly. Transforming our world: the 2030 Agenda for Sustainable Development. General Assembly Resolution 70/1. . 2015.

6. United Nations (2017a). The Sustainable Development Goals Report. New York: United Nations. 2017.

7. World Health Organization (WHO) (2010). Department of Health and Human Services, Office of Population Affairs, : 2010.

8. Ahman E, Shah I. Unsafe abortion: global and regional estimates of the incidence of unsafe abortion and associated mortality in 2008 . J Obstet Gynaecol Can. 2011;31(12):1149-58.

9. Bremner J, Frost A, Haub C, Mather M, Ringheim K, Zuehlke E. World population highlights: key findings from PRB's 2010 world population data sheet. . Popul Bull. 2010;65(2):1-12.

10. Rutstein SO. "Effects of preceding birth intervals on neonatal, infant and under-five years mortality and nutritional status in developing countries: evidence from the demographic and health surveys," nternational Journal of Gynecology \& Obstetrics,. 2005;89:pp. S7-S24.

11. Sedgh G, Hussain R. "Reasons for contraceptive nonuse among women having unmet need for contraception in developing countries," Studies in Family Planning. 2014;45(2):pp. 151-69.

12. Do M, Kurimoto N. Women's empowerment and choice of contraceptive methods in selected African countries. Int Perspect Sex Reprod Health. 2012:23-33.

13. Wado Y. Women's autonomy and reproductive healthcare-seeking behavior in Ethiopia. Calverton: ICF International, 2013.

14. Bourey C, Stephenson R, Bartel D, Rubardt M. Pile sorting innovations: exploring gender norms, power and equity in sub-Saharan Africa. . Global public health. 2012;7(9):995-1008.

15. International Labour Organization. Global Employment Trends for Women. 2009:p. 43.

16. Ministry for Foreign Affairs of Finland. Freedom to Choose: Sexual and Reproductive Health and Rights in Finland's Development Policy. 2010:p. 13.

17. Mboane R, Bhatta M. Influence of a husband's healthcare decision making role on a woman's intention to use contraceptives among Mozambican women. Reprod Health [Internet].12(1):1-8. 2015.

18. Christine D, Kira L, Allison K, Kevin G. Women's preferences for contraceptive counseling and decision making. Bone. 2008;23(1):1-7.

19. Bamiwuye S, Wet D, Adedini S. "Linkages between Autonomy, Poverty and Contraceptive Use in Two Sub-Saharan African Countries." African Population Studies. 201327 (2):164-73.

20. Wahaga $\mathrm{E}$. The gendered nature of productive and reproductive roles in the agricultural sector. . Int $\mathrm{J}$ Dev Sustain. 2018;7(1):120-46. 
21. Mussie A, Kiday H, Gebrezgabiher B, Gebremedhin G, Fitwi Tinsae A, Yemane B. Married Women's Autonomy and Associated Factors on Modern Contraceptive Use in Adwa Town, Northern Ethiopia. Science Journal of Public Health. 2014;2(4):pp. 297-304.

22. Mohammad H, Zaina P, M K. Effects of women's autonomy on maternal healthcare utilization in Bangladesh: Evidence from a national survey. sexual and reproductive health care. 2017;14:40-7.

23. Pauline O, Christine G. Women's autonomy in health care decisionmaking in developing countries: a synthesis of the literature. International Journal of Women's Health. 2016.

24. Dinku D, Daniel B, Zenebe M, Sintayehu M. Decision-Making Power of Married Women on Family Planning Use and Associated Factors in Dinsho Woreda, South East Ethiopia. Journal of contraception. 2020;11 15-23.

25. Acharya D, Bell J, Simkhada P, van Teijlingen E, Regmi P. Women's autonomy in household decisionmaking: a demographic study in Nepal. . Reprod Health. 2010;7(15).

26. Edossa Z, Debela T, Mizana B. Women's Decision on Contraceptive Use in Ethiopia: Multinomial Analysis of Evidence From Ethiopian Demographic and Health Survey. Health Services Research and Managerial Epidemiology. 2020;7:1-7.

27. Bogale B, Wondafrash M, Tilahun T, Girma E. Married women's decision making power on modern contraceptive use in urban and rural southern Ethiopia. . BMC Public Health. 2011;11:342.

28. Alemayehu B, Kassa G, Zeleke L, Abajobir A, Alemu A. Married Women's Decision-Making Power in Family Planning Use and its Determinants in Basoliben, Northwest Ethiopia. Journal of Contraception. 2020;11:43-52.

29. Alem S. Cross Sectional Study on Decision-making Power of Working and Nonworking Women in Family Planning and Reproductive Health and Rights in Gombak, Malaysia Article in Journal of W. J Womens Health Issues Care 2014;3(2).

30. Becker S, F. F-B, Schenck-Yglesias C. Husbands' and wives' reports of women's decision-making power in Western Guatemala and their effects on preventive health behaviors. Soc Sci Med. 2006;62(9):2313-26.

31. Grady W, Klepinger D, Billy J, Cubbins L. The role of relationship power in couple decisions about contraception in the US. . J Biosoc Sci. 2010;42(3):307-23.

32. Croft T, Marshall A, Allen C, Arnold F, Assaf S, Balian S. Guide to DHS statistics. Rockville: ICF. . 2018.

33. Mboane R, Bhatta M. Influence of a husband's healthcare decision making role on a woman's intention to use contraceptives among Mozambican women. Reproductive Health. 2015;12(1):1-8.

34. Haque S, Rahman M, Mostofa M, Zahan M. Reproductive health care utilization among young mothers in Bangladesh: does autonomy matter? . Womens Health Issues. 2012;22(2):e171-e80.

35. Patrikar S, Basannar D, Sharma M. Women empowerment and use of contraception. . Med J Armed Forces India. 2014;70:253-6.

36. Tilahun T, Coene G, Luchters S, Kassahun W, Leye E, Temmerman M, et al. Family planning knowledge, attitude and practice among married couples in Jimma Zone, Ethiopia. . PLoS One. 
2013;8(4):61335.

37. Beckman L. Communication, power, and the influence of social networks in couple decisions on fertility. . Determinants Fertil Dev Countries. 1983;2:415-43.

38. Kinoshita R. Women's domestic decision - making power and contraceptive use in rural Malawi. . Reprod Health. 2003;2(8).

39. PAULINE O, CHRISTINE G. FACTORS ASSOCIATED WITH WOMEN'S HEALTH CARE DECISIONMAKING AUTONOMY: EMPIRICAL EVIDENCE FROM NIGERIA. J Biosoc Sci 50(1): . 2018 50(1):70-85.

40. Senarath U, Gunawardena N. Women's autonomy in decision making for health care in South Asia. . Asia Pac J Public Health. 2009;21(2):137-43.

41. Iyayi F, Igbinomwanhia R, Bardi A, lyayi $\mathrm{O}$. The control of Nigerian women over their sexuality in an era of HIV/AIDS: A study of women in Edo State in Nigeria. . Int NGO J. 2012;6(5):113-21.

42. Becker S, Fonseca-Becker F, Schenck-Yglesias C. Husbands' and wives' reports of women's decisionmaking power in Western Guatemala and their effects on preventive health behaviors. . Soc Sci Med. 2006;62(9):2313-26.

43. Osuafor G, Maputle S, Ayiga N. Factors related to married or cohabiting women's decision to use modern contraceptive methods in Mahikeng, South Africa. Afr J Prm Health Care Med 2018;10(1).

44. Ilene S, Lisa C. Gender Relations and Reproductive Decision Making in Honduras. . International Family Planning Perspectives. 2005;31:131-9.

45. Eshete A, Adissu Y. Women's Joint Decision on Contraceptive Use in Gedeo Zone, Southern Ethiopia: A Community Based Comparative Cross-Sectional Study. International Journal of Family Medicine. 2017.

46. Dabere N, Abebe G, Muluemebet A, Tesfaye S, Kebede D. Factors associated with women's autonomy regarding maternal and child health care utilization in Bale Zone: a community based cross-sectional study. . BMC Women's Health. 2014 14:79.

47. Haque S, Rahman M, Mostofa M, Zahan M. Reproductive health care utilization among young mothers in Bangladesh: does autonomy matter? Women's Health Issues 2012;22(2):e171-80. 